\title{
Basic concepts and curriculum theory in education
}

\author{
Indah Rizki Ramadani $\left.{ }^{*}\right)$, Firman ${ }^{1}$, Riska Ahmad ${ }^{1}$ \\ ${ }^{1}$ Pasca Sarjana Bimbingan dan Konseling, Universitas Negeri Padang, Indonesia \\ *) Correspondence: indahrizkiramadani29@gmail.com
}

\begin{abstract}
The curriculum has a domain in education that is contained in various substances, namely: curriculum as part of the field of study, curriculum as a substance in the teaching plan, and curriculum as part of a system. The curriculum functions in shaping and developing cognitive, affective and psychomotor aspects of humans by achieving the vision, mission and goals of national education. The curriculum as a tool can be realized in the form of programs, namely learning activities and experiences that must be carried out by teachers and students in the learning process. This research is a research with a literature study approach that looks at how the nature and description of a dynamic and flexible curriculum and always experiences shifts and changes following the direction and goals of education, which every year the curriculum is continuously updated so as not to be left behind by the times, making the curriculum easily implemented. in every educational institution. The purpose of the curriculum is to produce the best graduates who are knowledgeable, have character, uphold the values of cultural, moral, national norms and have a high level of religiosity.
\end{abstract}

Keywords: Theory, basic concepts of the curriculum

Article History: Received on 20/01/2021; Revised on 21/01/2021; Accepted on 10/02/2021; Published Online: 19/02/2021.

This is an open access article distributed under the Creative Commons Attribution License, which permits unrestricted use,
distribution, and reproduction in any medium, provided the original work is properly cited. (C)2021 by author.

\section{INTRODUCTION}

Kurikulum dan pendidikan bagaikan dua sisi mata uang yang tidak dapat dipisahkan. Kurikulum menempati posisi terpenting dan strategis dalam pendidikan karena secara keseluruhan isi yang dimuat dalam kurikulum merupakan visi dan misi serta tujuan dari pendidikan harus menyesuaikan dengan kebutuhan masyarakat (Fitrah, 2015). Suradnya menyatakan bahwa sifat yang dinamis dan fleksibel dari kurikulum akan selalu mengalami pergeseran dan perubahan mengikuti arah dan tujuan dari pendidikan yang mana setiap tahunnya kurikulum terus diperbaharui agar tidak tertinggal dari perkembangan zaman (Suradnya, 2009). Mengingat bahwa adanya tuntutan bahwa siswa diharapkan mampu untuk belajar di dalam dan di luar kelas agar sekolah dapat mencetak atau menghasilkan siswa yang berkualitas jadi kurikulum akan menyesuaikan diri dengan berbagai tuntutan akan hal tersebut.

Menurut Undang-Undang Nomor 20 Tahun 2003 tentang Sistem Pendidikan Nasional (SISDIKNAS) kurikulum merupakan sekumpulan rencana dan pengaturan mengenai tujuan, isi, dan materi pembelajaran serta metode yang digunakan untuk melaksanakan kegiatan pembelajaran untuk mencapai tujuan pendidikan tertentu. (UU 
No.20 Tahun 2003 tentang Sisdiknas) Mengingat pentingnya peran kurikulum dalam pendidikan yang harus mengikuti perkembangan kehidupan manusia, sehingga perlu memahami konsep dasar dari kurikulum itu sendiri pada saat penyusunan kurikulum. Setiap orang, kelompok masyarakat, atau bahkan ahli pendidikan memiliki penafsiran yang berbeda terhadap kurikulum. Kurikulum dirancang sebagai desain dalam pendidikan dan memiliki kedudukan yang sangat penting dalam segala aspek kegiatan pembelajaran. Berdasarkan penelitian yang telah dilakukan oleh para ahli, pemahaman tentang kurikulum dapat dilakukan dari dua sisi yang berbeda, yaitu berdasarkan sudut pandang lama dan sudut pandang baru (Hamalik, 2008).

Kurikulum mempunyai fungsi sebagai nafas atau inti dari proses pendidikan di sekolah untuk memberdayakan siswa yang berpotensi (Tamami, 2016). Kurikulum juga dikatakan sebagai media yang menentukan terhadap keberhasilan proses pendidikan, dalam artian bahwa tanpa kurikulum yang baik dan sesuai akan sulit untuk mencapai tujuan pendidikan yang dicita-citakan (Hartatik 2016).

Materi dan pembahasan terkait kurikulum dalam kajian ini hanya berfokus pada pembahasan mengenai teori dan konsep dasar kurikulum dalam pendidikan. Pemaparan singkat mengenai teori dan konsep dasar kurikulum dalam pendidikan ini diharapkan dapat menjadi bahan informasi serta menambah refrensi pengetahuan bagi stakeholders, dan pembaca lainnya. Tujuan dari kurikulum yaitu menghasilkan lulusan terbaik yang berilmu pengetahuan, berkarakter, menjunjung tinggi nilai-nilai norma budaya, moral, kebangsaan serta memiliki tingkat religiusitas yang tinggi. Berdasarkan hal ini, diketahui bahwa kurikulum dan pendidikan saling berkaitan dan tidak dapat dipisahkan bagaikan dua sisi mata uang.

\section{METHOD}

Penelitian ini menggunakan metode penelitian studi kepustakaan atau literatur review. Studi kepustakaan merupakan salah satu dari sekian banyak metode penelitian yang bertujuan untuk mengumpulkan berbagai macam data yang didapat dari berbagai macam sumber seperti ensiklopedi, jurnal, buku, dokumentasi, serta hasil penelitian yang dilakukan oleh peneliti terdahulu berkaitan dengan topik serta variabel dalam penelitian (Nursalam 2016). Pada penelitian ini penulis menjadikan sumber primer untuk digunakan sebagai bahan refrensi ialah sumber tulisan asli yang diperoleh dari beberapa penelitian terdahulu. Sedangkan sumber sekunder diperoleh dari buku teks dan UUD tentang Sisdiknas.

\section{RESULTS AND DISCUSSION}

Secara bahasa istilah kurikulum yang dalam bahasa Inggris ditulis curriculum berasal dari bahasa Yunani yaitu curir yang berarti pelari, dan curere yang berarti "tempat berpacu". Tidak heran jika dilihat dari arti harfiahnya, istilah kurikulum tersebut pada awalnya digunakan dalam dunia olah raga, yang diartikan menjadi "pelari dan tempat berpacu", yang mengingatkan kita pada jenis olah raga atletik. Makna kurikulum berawal dari kata curir dan curere, berdasarkan istilah kurikulum diartikan sebagai "Jarak yang harus ditempuh oleh seorang pelari mulai dari garis start sampai menuju garis finish sebagai akhir untuk memperoleh medali atau penghargaan". Pengertian tersebut 
kemudian di adaptasikan dalam dunia pendididikan dan diartikan sebagai "Sejumlah mata pelajaran yang diharuskan oleh siswa untuk ditempuh dari awal hingga akhir program pendidikan demi memperoleh ijazah". Dari pengertian tersebut, terdapat dua hal pokok yaitu adanya mata pelajaran yang harus dilalui oleh siswa agaridapat memperoleh ijazah setelah dapat menyelesaikan berbagai mata pelajaran yang dilalui selama proses pembelajaran. Kurikulum merupakan suatu program dalam pendidikan yang berisikan berbagai macam bahan pengajaran dan pengalaman belajar yang diprogramkan, direncanakan secara sistematik berdasarkan norma-norma yang berlaku untuk dijadikan pedoman dalam proses pembelajaran bagi tenaga kependidikan dan peserta didik untuk mencapai tujuan pendidikan (Dakir, 2004).

Menurut S. Nasution, kurikulum dapat dikatakan sebagai suatu perencanaan yang bertujuan untuk kelancaran proses belajar mengajar di bawah bimbingan dan tanggung jawab sekolah atau lembaga pendidikan beserta staf pengajar. Selain itu, Nasution menjelaskan sejumlah ahli teori kurikulum yang meyakini bahwa kurikulum tidak hanya mencakup semua kegiatan yang direncanakan, tetapi juga peristiwa yang terjadi di bawah pengawasan sekolah. Oleh karena itu, kegiatan kurikuler atau ekstrakurikuler sering disebut sebagai kegiatan kurikulum yang formal (S. Nasution, 1989).

Kurikulum adalah keseluruhan rencana, fasilitas, dan kegiatan yang dilaksanakan untuk mencapai visi dan misi suatu lembaga pendidikan atau pelatihan yang disesuaikan dengan masing-masing lembaga. Dengan demikian, terlaksananya kurikulum diharapkan dapat mendorong keterlaksanaan dan keberhasilan suatu lembaga pendidikan masingmasing diantaranya ialah: (1) Dengan adanya tenaga pendidik (SDM) yang berkompeten, (2) Fasilitas serta sarana dan prasarana yang memadai. (3) Fasilitas pendukung sebagai pelengkap keterlaksaan pendidikan. (4) Tenaga penunjang sebagai tambahan SDM seperti staf pada bagian administrasi, pustakawan, staf ahli atau asisten laboratorium, serta tenaga pembimbing lainnya. (5) Keuangan atau sumber dana yang mendukung. (6) Manajemen lembaga yang baik. (7) Tingkat religiusitas yang tinggi serta menjunjung nilai-nilai norma, budaya, moral, dan kebangsaan. (8) Memilih pemimpin yang visioner transparan dan akuntabel (Hasbullah, 2007).

Kurikulum dapat diartikan sebagai sebuah rancangan untuk seluruh kegiatan pembelajaran sebagai bahan acuan dalam perencanaan, pelaksanaan, pemantauan, dan evaluasi semua kegiatan pendidikan untuk mencapai tujuan dari pendidikan. Kurikulum juga dapat dijadikan sebagai acuan dasar dalam pembentukan serta tercapainya kompetensi lulusan setiap program akademik pada jenjang program studi tersebut, diharapkan kurikulum yang dirancang oleh pihak satuan pendidikan akan menghasilkan lulusan terbaik dan dapat diterima untuk melanjutkan pendidikan kejenjang yang lebih tinggi. Pencapaian pelaksanaan kurikulum sangat diperlukan ketaatan akan azas serta adanya perencanaan pengembangan dan pemutakhiran kurikulum secara berkala dan berkesinambungan serta berjalannya kegiatan perencanaan, pengembangan dan pemutakhiran kurikulum yang akan dilaksanakan (Firman. dkk 2013).

Setiap kurikulum merupakan pola dan susunan mata pelajaran yang harus ditempuh oleh peserta didik dalam kegiatan pembelajaran. Kedalaman muatan kurikulum pada setiap mata pelajaran ditiap-tiap satuan pendidikan harus dikuasai oleh 
peserta didik sesuai dengan beban belajar yang tercantum dalam struktur kurikulum. Kompetensi yang dimaksud ialah kompetensi dasar yang dikembangkan berdasarkan standar kompetensi lulusan (Yamin, 2012).

\section{Konsep Dasar Kurikulum}

Secara konseptual kurikulum memiliki ranah tersendiri dalam pendidikan yang dimuat dalam berbagai substansi, adapun substansi yang memuat kurikulum diantaranya ialah sebagai berikut:

1. Kurikulum sebagai bagian dari Bidang Studi

Pada bidang studi kurikulum berfungsi sebagai suatu disiplin ilmu yang dikaji pada lembaga pendidikan misalnya pada Perguruan Tinggi baik Negeri maupun Swasta. Tujuannya untuk mengembangkan ilmu dan sistem dalam kurikulum. Dengan cara melakukan kajian serta mempelajari tentang konsep dasar kurikulum bagianbagian kurikulum, serta melakukan kegiatan penelitian untuk menemukan hal-hal baru yang dapat menyempurnakan dan memperkaya bidang studi penelitian dalam kurikulum.

2. Kurikulum sebagai Substansi dalam Rencana Pengajaran

Kurikulum sebagai substansi maksudnya adalah kurikulum yang strukturnya memuat tujuan dari lembaga yang ingin dicapai sebagai materi yang dikenalkan dalam kegiatan pengajaran, perangkat pengajaran dan jadwal pengajaran. Kurikulum disusun dalam bentuk dokumen tertulis yang memuat tujuan yang telah disepakati dan dicapai oleh para tim dalam merumuskan kurikulum yang telah bersama oleh para dan pemegang kebijaksanaan serta stakeholder yang terkait tentang tujuan, bahan ajar, kegiatan belajar-mengajar, jadwal, dan penilaian dalam kurikulum.

3. Kurikulum sebagai bagian dari Suatu Sistem

Kurikulum sebagai bagian dari suatu sistem memiliki arti bahwa kurikulum merupakan bagian dari keseluruhan struktur organisasi sekolah atau sistem sekolah atau dapat juga disebut dengan struktur organisasi sekolah secara keseluruhan atau subsistem dari sistem sekolah. Hasil dari sistem kurikulum adalah pembentukan tersusunnya kurikulum. Kurikulum sebagai sistem memiliki fungsi untuk melihat bagaimana kurikulum tersebut terus berjalan secara dinamis. (Sukmadinata, 2015).

\section{Teori Kurikulum}

Menurut Bobbit, inti dari teori kurikulum adalah kehidupan manusia. Meskipun kehidupan manusia cenderung berbeda-beda namun pada dasarnya sama, terbentuk dari berbagai struktur dan rangkaian sistem dalam kehidupan manusia tersebut. Pendidikan berupaya dalam mempersiapkan struktur rangkaian kehidupan tersebut dengan teliti dan sempurna. Setiap tingkatan dan lingkungan kehidupan membutuhkan kecakapan dalam hal pengetahuan, keterampilan, sikap, kebiasaan, dan penghargaan tertentu. Hal tersebut bertujuan agar kurikulum dapat disusun dengan semaksimal mungkin agar dapat memuat tatanan dalam kehidupan dan dapat mengikuti perkembangan zaman serta perubahan sosial yang ada di masyarakat (Franklin Babbit, 1918).

Perkembangan teori kurikulum selanjutnya dikemukakan oleh Hollis Caswell, sebagai ketua departemen pengembang kurikulum pada beberapa negara bagian di Amerika Serikat (Tennessee, Alabama, Florida dan Virginia). Ia mengembangkan konsep 
kurikulum yang berpusat pada masyarakat atau berpusat pada pekerjaan (society centered) sehingga Caswell mengembangkan kurikulum yang bersifat interaktif. Saat merumuskan pengembangan kurikulumnya, Caswell menekankanipada partisipasi guru dalam menentukan kurikulum, menentukan struktur organisasi kurikulum, merumuskan makna kurikulum, menetapkan tujuan, memilih konten, menentukan kegiatan pembelajaran, merancang desain kurikulum, dan mengevaluasiihasil pembelajaran (Doll, 1974).

Sukmadinata mengemukakan empat pertanyaan utama yang menjadi inti kajian dalam penelitian kurikulum: (1) Apa tujuan pendidikan yang harus dicapai sekolah? (2) Pengalaman pendidikan apa yang harus diberikan untuk mencapai tujuan? (3) Bagaimana mengorganisasikan pengalaman pendidikan secara efektif? (4) Bagaimana sikap kita dalam menentukan apakah tujuan tersebut telah tercapai? (Sukmadinata 2000). Kurikulum dengan pendidikan bagaikan dua sisi mata uang yang tidak dapat dipisahkan. Kurikulum disusun dengan mengacu pada beberapa kurikulum, suatu teori kurikulum diturunkan atau diuraikan dari teori pendidikan tertentu. Kurikulum dapat dilihat sebagai rencana konkret untuk menerapkan teori pendidikan. Untuk itu agar lebih memahami hubungan antara kurikulum dengan pendidikan, beberapa teori pendidikan dan model konseptual kurikulum diusulkan dari masing-masing teori tersebut. Ada empat teori pendidikan yang banyak dibicarakan para ahli pendidikan dan dipandang mendasari pelaksanaan pendidikan, sebagai berikut:

1. Pendidikan Klasik

Pendidikan klasik merupakan sebuah konsep pendidikan awal. Konsep pendidikan ini didasarkan pada pandangan yaitu para pemikir/ahli sebelumnya telah menemukan semua warisan budaya, yaitu pengetahuan, gagasan, dan nilai-nilai. Fungsi pendidikan adalah memelihara dan melestarikan semua warisan budaya tersebut agar dapat di wariskan kepada generasi penerus. Guru atau pendidik tidak perlu susah untuk mencari materi dan menciptakan pengetahuan baru, ide dan nilai dalam pendidikan karena semuanya sudah ada tinggal menguasai serta mengajarkannya kepada peserta didik. Teori yang ada dalam pendidikan diambil dari khazanah ilmu pengetahuan, berupa disiplin ilmu yang ditemukan dan dikembangkan oleh para ahli di masa lampau. Materi ilmiah yang diperoleh dari disiplin ilmu pengetahuan telah disusun secara logis dan sistematis.

Tugas guru dan para pengembang kurikulum adalah memilih dan menyajikan materi ilmu tersebut disesuaikan dengan tingkat perkembangan dan kemampuan peserta didik. Sebelum menyampaikan materi ilmu pengetahuan dengan baik, para pendidik atau calon pendidik harus terlebih dahulu mempelajari apa yang akan ia sampaikan. Tugas pendidik atau guru tidak hanya untuk memberikan pengetahuan terkait materi pembelajaran, tetapi juga melatih keterampilan dan menanamkan nilai kepada peserta didik. Memberikan nilai-nilai yang berbeda dengan mengajarkan pengetahuan yang dalam bentuk penyampaian informasi, namun perlu direfleksikan dalam perilaku sehari-hari. Menurut konsep pendidikan klasik, guru atau pendidik adalah ahli di bidang sains sekaligus contoh atau teladan sejati dari kepribadian yang ideal. Siswa adalah orang yang menerima pengajaran dari pendidik, sebagai penerima informasi yang pasif. Namun, dalam pendidikan klasik siswa bekerja keras menguasai 
apa yang akan diajarkan dan dibagikan oleh guru. Pendidikan berfokus pada pengembangan kecerdasan, emosi dan psikomotorik (Sukmadinata, 2015).

2. Pendidikan Pribadi

Pendidikan pribadi lebih mengutamakan peranan siswa. Konsep pendidikan ini beranggapan bahwa sejak lahir anak memiliki potensi untuk berpikir, bertindak, memecahkan masalah, serta belajar dan berkembang secara mandiri. Pendidikan ibarat taman kanak-kanak, perannya menciptakan lingkungan yang mendukung dan menghindari organisme berbahaya. Ibarat petani mengupayakan tanah yang gembur, pupuk, air, udara, dan sinar matahari yang sesuai dengan kebutuhan dan perkembangan tanaman (peserta didik). Pendidikan didasarkan pada kebutuhan dan minat peserta didik, peserta didik menjadi subjek utama dalam pendidikan, peserta didik memegang peranan penting dalam pendidikan. Sedangkan pendidik berada pada posisi kedua, hanya berperan dalam menyampaikan informasi atau sebagai panutan dalam pembelajaran yang berkontribusi hanya $25 \%$ dari seluruh proses pembelajaran. Mengapa peserta didik menjadi peran utama? Karena peserta didik diharapkan dapat memenuhi $75 \%$ dari proses pembejaran yang ia dapatkan dari membaca, mencari infromasi dan belajar secara mandiri. Pendidik dapat membantu siswa menghasilkan gagasan baru dan bertindak sebagai pemandu, motivator, fasilitator, dan pelayan bagi siswa. Selain itu pendidik juga dapat berperan sebagai psikolog untuk memahami segala kebutuhan dan masalah yang dihadapi oleh peserta didik (Sukmadinata 2015).

3. Teknologi Pendidikan

Teknologi pendidikan memiliki peran yang sama dengan pendidikan klasik dalam proses pemberian informasi. Selain memiliki persamaan keduanya juga mempunyai perbedaan, dalam teknologi pendidikan yang lebih diutamakan ialah pembentukan dan penguasaan kemampuan bukanlah tentang pelestarian dan pemeliharaan budaya lama, tetapi kepedulian terhadap masa kini dan masa depan, berbeda dengan pendidikan klasik yang lebih melihat ke masa lalu daripada masa kini.

Perkembangan teknologi pendidikan sangat dipengaruhi dan diwarnai oleh perkembangan ilmu dan teknologi. Hal itu terlihat, sebab teknologi pendidikan bertolak dari penerapan prinsip-prinsip ilmu dan teknologi dalam pendidikan. Teknologi tersebut telah masuk ke semua sisi kehidupan, termasuk dalam pendidikan itu sendiri (Sukmadinata 2015).

4. Pendidikan Interaksional

Bertolak dari pemikiran manusia sebagai makhluk sosial, konsep pendidikan yang memiliki tujuan memanusiakan manusia. Hal ini terlihat dari kehidupan manusia yang membutuhkan manusia lain, selalu hidup bersama, berinteraksi dan bekerja sama karena kebersamaan dan kerja sama semacam ini, mereka dapat hidup, berkembang dan dapat mencari nafkah serta menyelesaikan berbagai masalah yang ada dihadapan mereka. Bisa dibayangkan bagaimana jadinya jika tinggal sendirian di sebuah pulau terpencil. Bila lingkungannya mendukung mungkin ia dapat bertahan hidup, tetapi jika tidak mungkin dapat hidup atau dapat mencapai kemajuan yang 
ingin dicapai oleh orang-orang yang hidup bersama dengan orang lain (Sukmadinata 2015).

Sebagai wujud dalam bentuk kehidupan juga melibatkan kerjasama dan interaksi. Dalam pendidikan klasik dan teknologi, interaksi terjadi secara sepihak dari guru ke siswa, sedangkan dalam pendidikan terjadi interaksi dari siswa ke guru. Pendidikan interaktif menekankan pada interaksi dua pihak antara guru kepada siswa dan siswa kepada guru. Lebih luas lagi, interaksi semacam ini juga terjadi antara siswa dengan bahan ajar dengan lingkungan, serta antara pemikiran dengan kehidupan siswa. Interaksi pembelajaran yang terjadi dalam berbagai bentuk dialog merupakan bagian dari pendidikan bersifat interaksional (Sukmadinata, 2015).

Dalam penjabaran ini terlihat teori pendidikan telah dirumuskan oleh para ahli dan beberapa pendidik jug atelah mengaplikasikannya di dunia pendidikan, amun perlu diperhatikan lagi bahwa ada lebih dan kurangnya dari masing-masing teori tersebut, handaknya sebagai pendidik mereka menggunakan teori yang mana saja pada setiap waktu yang telah disesuaikan dengan kondisi pada saat itu.

\section{Kedudukan Kurikulum dalam Pendidikan}

Pendidikan dilaksanakan melalui interaksi antara pendidik dengan peserta didik yang bertujuan untuk membantu peserta didik dalam menguasai tujuan pendidikan. Interaksi pendidikan dapat terjadi dalam lingkungan keluarga, sekolah, atau masyarakat (Hasbullah, 2006). Dalam lingkungan keluarga, interaksi pendidikan terjadi antara orangtua sebagai pendidik dan anak sebagai peserta didik. Interaksi ini tidak memerlukan interaksi tertulis untuk dijadikan acuan. Orangtua biasanya tidak mempunyai rencana yang jelas dan rinci untuk memandu anak-anak mereka, bagaimana cara mendidik, dan apa isi dari pendidikan yang mereka terima (Mulyasa, 2009). Interaksi pendidikan antara orang tua dengan anaknya juga sering tidak disadari. Dalam kehidupan keluarga interaksi pendidikan dapat terjadi setiap saat, setiap kali orang tua bertemu, berdialog, bergaul, dan bekerjasama dengan anak-anaknya. Pada saat itu banyak perilaku dan perlakuan yang diberikan kepada anak secara langsung, sehingga kemungkinan terjadinya kesalahan pendidik tinggi. Orang tua yang merupakan pendidik tidak selalu melakukan persiapan secara matang. Meskipun menjadi pendidik karena statusnya sebagai ayah dan ibu, meskipun mungkin saja sebenarnya mereka belum siap untuk tugas ini, mereka menjadi pendidik karena status mereka sebagai orang tua. Karena bersifat informal, tidak ada desain khusus, dan terkadang tidak terealisasi, maka pendidikan di lingkungan keluarga disebut pendidikan informal, sehingga tidak mempunyai kurikulum formal yang dituliskan secara resmi (Mulyasa, 2012).

Pendidikan yang ada dalam ruang lingkup sekolah disebut pendidikan yang bersifat formal. Guru berperan sebagai pendidik di sekolah yang telah dipersiapkan secara formal pada lembaga pendidikan guru. Seorang guru pastinya telah mempelajari ilmu pengetahuan, keterampilan, dan seni yang akan ia aplikasikan dalam lingkup sekolah untuk menjadi guru. Seorang guru telah dibina untuk memiliki kepribadian yang dapat dijadikan contoh sebagai pendidik. Seorang guru juga melaksanakan tugasnya sebagai pendidik dengan rencana dan persiapan yang matang. Dalam proses pembelajaran berlangsung, seorang guru harus melakukan kegiatan pembelajaran 
dengan tujuan yang alat jelas, serta mempersiapkan bahan-bahan untuk dijadikan bahan ajar demi menunjang kelancaran proses belajar mengajar dengan baik dan merinci, dengan cara dan alat-alat yang telah dipilih dan dirancang dengan baik. Di sekolah guru telah merencanakan dan secara sadar melakukan interaksi pendidikan yang interaktif. Dalam lingkungan sekolah telah ada kurikulum formal, sehingga pendidikan yang dilaksanakan oleh guru disekolah disebut dan ditetapkan sebagai pendidikan formal (Mulyasa, 2012).

Pada lingkungan yang ada dalam masyarakat bentuk interaksi pendidikan juga terjadi, mulai dari yang sangat menyerupai pendidikan formal (mirip dengan pendidikan di sekolah) hingga bentuk pendidikan yang kurang formal seperti ceramah, dan pergaulan kerja. Seseorang yang berperan sebagai guru atau pendidiknya juga bervariasi dari yang memiliki latar belakang pendidikan khusus sebagai guru, sampai dengan seseorang yang melaksanakan berperan sebagai pendidiknya hanya berdasarkan pengalaman atau seseorang yang dianggap bisa untuk dijadikan contoh dalam masyarakat. Format kurikulumnya pun beragam, mulai dari kurikulum formal dan tertulis hingga rencana dalam pembelajaran yang hanya ada dibenak pendidik atau penceramah serta bentuk keteladanan yang ada pada pemimpin yang dijadikan pendidik sebagai bahan pembelajaran (Sukmadinata, 2015).

Pendapat lain juga menyatakan bahwa kurikulum disebut sebagai inti pendidikan dan menjadi ciri utama pada setiap sekolah sebagai institusi yang bergerak dalam pelayanan pendidikan. Kurikulum pendidikan didalamnya terdiri dari lima komponen, yaitu :

\section{Tujuan pendidikan}

Saat ini dalam praktik pendidikan, baik dalam lingkup keluarga, sekolah maupun masyarakat, terdapat banyak tujuan pendidikan yang diinginkan oleh pendidik agar dapat dicapai oleh peserta didiknya.

Menurut Langeveld macam-macam tujuan pendidikan sebagai berikut:
a. Tujuan umum
b. Tujuan tidak sempurna
c. Tujuan sementara
d. Tujuan menengah
e. Tujuan yang berketepatan (Langeveld, 1967)

2. Isi/materi pendidikan

Isi/materi dalam pendidikan adalah segala sesuatu yang diberikan langsung oleh pendidik kepada peserta didik untuk mencapai tujuan pendidikan. Dalam proses pendidikan yang dilaksanakan di lingkungan keluarga, sekolah dan masyarakat, syarat utama pemilihan materi bahan ajar adalah sebagai berikut:

a. Materi yang diajarkan harus disesuaikan dengan tujuan.

b. Materi yang diajarkan harus disesuaikan dengan siswa/peserta didik. (Bahri, 2011).

3. Strategi

Secara umum metode ini berkaitan dengan pelaksanaan gagasan, perencanaan, dan penyelesaian semua kegiatan pembelajaran dalam kurun waktu tertentu. Untuk 
mencapai maksud dan tujuan yang telah ditentukan oleh sekelompok orang maka strategi dan rencana ideologis dirumuskan oleh semua pihak.(Yamin, 2012)

4. Pengelolaan Kurikulum

Melalui pembentukn model kependidikan, pendidik, dan sumber daya manusia untuk pengelolaan pendidikan guna meningkatkan mutu serta kualitas pendidikan itu sendiri. Kurikulum sangat berperan dalam menentukan keberhasilan dalam pelaksanaan kegiatan belajar mengajar yang terbaik, sehingga perlu adanya pengelolaan yang dapat dikelolah sesuai dengan ketentuan sebagai berikut:

a. Kegiatan perencanaan

b. Kegiatan implementasi

c. Kegiatan evaluasi (Yamin, 2012)

5. Evaluasi)

Kegiatan maupun tindakan yang dilaksanakan dengan maksud tertentu untuk suatu proses yang berlangsung dalam rangka untuk menentukan nilai yang berdasarkan dari segala sesuatu pada lembaga pendidikan. Dalam pengelolaann pendidikan disekolah, guru bertanggung jawab untuk mengajar, dan guru menjadi pelaksana utama utama kurikulum.

Kegiatan pembelajaran diwujudkan dalam bentuk interaksi antara guru dengan siswa. Siswa memiliki tugas pokok dalam belajar yakni berusaha untuk memperoleh perubahan perilaku atau pencapaian kemampuan atau potensi akademik tertentu yang berdasarkan dari pengalaman belajar yang telah ia peroleh dari proses interaksi dengan lingkunganya. Untuk mencapai tujuan dari pendidikan, guru atau tenaga pendidik berupaya agar dalam pemberian informasi pembelajaran kepada siswa melalui proses atau strategi tertentu, dan mengevaluasi hasil pembelajaran untuk mengetahui sejauh mana proses dan hasil dari pembelajaran yang diberikan oleh pendidik.

Meski kurikulum memiliki posisi sentral dalam pendidikan, keberadaan kurikulum masih menjadi alat yang permanen. Kurikulum bermakna apabila benarbenar di implementasikan dengan baik dan tepat dalam setiap praktik pembelajaran (kurikulum sebagai kegiatan), dan dapat dijalankan secara efektif dan efisien dengan arti bahwa kurikulum dijadikan sebagai hasil dalam pendidikan (Ihsan 2005).

\section{Fungsi dan Tujuan Kurikulum}

Kurikulum sebagai organisasi dalam pembelajaran disusun dan disiapkan untuk siswa atau peserta didik sebagai salah satu yang akan dikonsumsi dalam pendidikan mereka. Dengan adanya kurikulum siswa diharapkan mampu mendapatkan pengalaman baru yang kelak dikemudian hari akan dapat dikembangkan selaras dengan perkembangan mereka yang berguna dalam melengkapi bekal hidup siswa tersebut (Ismawati 2012).

Pengembangan kurikulum selalu menggunakan berbagai prinsip-prinsip dan pendekatan yang disesuaikan dengan keadaan pada lembaga pendidikan. Hal ini mempunyai arti bahwa kurikulum itu diharapkan dapat menghasilkan output yang 
berkualitas, mempunyai nilai relevansi terhadap pengembangan atau apa-apa yang akan terjadi pada masa yang akan datang. Dengan kata lain, program-program yang ditawarkan oleh dunia pendidikan yang diharapkan dapat memiliki arti hidup yang mendalam bagi peserta didik, keluarga dan bangsa menurut perkembangan zaman (Abdullah Idi 2014).

Fungsi kurikulum merupakan alat untuk mencapai tujuan pendidikan. Selain itu fungsi kurikulum juga merupakan alat untuk membentuk manusia seutuhnya sesuai dengan visi, misi dan tujuan pendidikan nasional, termasuk berbagai tingkatan tujuan pendidikan. Kurikulum sebagai alat dapat diwujudkan dalam bentuk program, yaitu kegiatan dan pengalaman belajar yang harus dilaksanakan oleh guru dan peserta didik dalam proses pembelajaran. Program tersebut harus dirancang secara sistematis, logis, terencana, dan sesuai dengan kebutuhan, sehingga dapat dijadikan acuan bagi seorang guru dan peserta didik dalam melaksanakan proses pembelajaran yang efektif (Zainal Arifin 2011). Penelitian yang dilakukan oleh Ririn \& Rizal (2020) menyatakan bahwa keterampilan guru pada abad 21 terhadap implementasi kurikulum 2013 di SMK sangat berkontribusi karena seiring perkembangan zaman guru mampu mengembangkan kemampuan ilmu pengetahuan yang ia miliki dan menghubungkannya dengan perkembangan kurikulum yang ada saat ini. Menjadikan siswa untuk berpikir secara kritis dan logis dengan menguasai teknologi yang ada, dan sama-sama berkeinginan untuk mengasah keterampilan soft skill maupun hard skill, yang berguna untuk menghadapi tantangan dalam pendidikan pada abad 21.

Sesuai dengan pembahasan diatas terkait implementasi kurikulum dalam pendidikan hendaknya kemampuan dalam pengembangan kurikulurn pendidikan, diimplementasikan sejak dini agar siswa dapat mengaplikasikan pendidikan karakter sesuai dengan tujuan dari kurikulum 2013. Pengembangan pendidikan karakter ditujukan untuk mengoptimalkan penyelenggaraan pendidikan karakter di sekolah-sekolah khususnya pada jenjang pendidikan SD. Desain pendidikan karakter yang dikembangkan adalah terintegrasi mat. pelajaran. Dalam konteks ini pendidikan karakter yang dikembangkan menyatu dalam pembelajaran sesuai dengan desain kurikulurn 2013 yang bemuansa tematik. Penyusunan buku teks mengenai desain kurikulum pendidikan karakter diharapkan menjadi panduan bagi guru dan praktisi pendidikan untuk melaksanakan pendidikan karakter di sekolah. Desain kurikulum pendidikan karakter dibuat terintegrasi mata pelajaran karena pengembangannya disesuaikan dengan kebutuhan pembelajaran yang dibuat dengan rancangan tematik (Hidayati 2014). Tujuan kurikulum sekolah menurut Ismawati ada dua macam yang pertama yaitu tujuan yang ingin dicapai sekolah secara keseluruhan. Tujuan ini meliputi aspek pengetahuan, ketrampilan, sikap, dan nilai-nilai yang diharapkan oleh lulusan sekolah. Tujuan ini disebut dengan tujuan institusional atau kelembagaan. Kemudian tujuan yang kedua yaitu tujuan yang ingin dicapai oleh setiap bidang studi. Tujuan ini disebut tujuan kurikuler, adalah penjabaran dari tujuan institusional. Tujuan ini meliputi tujuan instruksional yang diharapkan dimiliki siswa setelah mempelajari setiap bidang studi dan pokok bahasanya dalam proses pengajaran (Ismawati 2012).

Tujuan kurikulum dalam setiap satuan pendidikan harus melihat kearah pencapaian tujuan pendidikan secara nasional, sebagaimana telah ditetapkan pada Undang-Undang Tahun 2003 tentang Sistem Pendidikan Nasional. Dalam skala yang 
lebih luas, kurikulum merupakan suatu alat pendidikan dengan tujuan untuk mengembangkan sumberdaya manusia yang berkualitas. Kurikulum selalu menyediakan kesempatan-kesempatan yang luas bagi para peserta didik untuk mengalami berbagai macam proses pendidikan dan pembelajaran yang berguna untuk mencapai target tujuan pendidikan nasional khususnya dan sumberdaya manusia yang lebih berkualitas pada umumnya (Hamalik, O. 2008). Berdasarkan penelitian yang dilakukan oleh Bentri (2014) tentang Formulasi Strategi Penerapan Blended Learning dalam Implementasi Kurikulum di Jurusan KTP FIP Universitas Negeri Padang, penelitian ini dilakukan untuk menelaah struktur Kurikulum 2013 dan KTSP dan melihat perbedaannya dengan kurikulum 2004 serta keterkaitan tujuan Pendidikan Nasional dengan kompetensi, standard kompetensi dan kompetensi dasar. Untuk itu dalam meningkatkan strategi pembelajaran yang relevan dengan teknologi saat ini, UNP sudah menyediakan e-learning pada portal UNP. Namun, melihat karakteristik belajar mahasiswa, belum memungkinkan untuk melakukan online learning sepenuhnya, perlu dipertahankan pertemuan tatap muka. Oleh karena itu, dengan memanfaatkan fasilitas berbasis jaringan internet, perlu dirumuskan formulasi strategi blended learning yang tepat dalam implementasi kurikulum pada mata kuliah kajian kurikulum sekolah. Hasil yang diperoleh dari penelitian ini ialah pembelajaran tatap muka tetap dipertahankan dan dikombinasikan dengan online learning hasil persentase daripenelitian ini dirumuskan formula online learning $62,5 \%$ dan formula pertemuan tatap muka 37,5\%.

Berdasarkan penjelasan diatas mengenai konsep dan teori kurikulum dapat disimpulkan bawah secara konseptual kurikulum memiliki ranah dalam pendidikan yang dimuat dalam berbagai substansi yaitu: kurikulum sebagai bagian dari bidang studi, kurikulum sebagai substansi dalam rencana pengajaran, dan kurikulum sebagai bagian dari suatu sistem. Kurikulum disebut sebagai inti pendidikan dan menjadi ciri utama sekolah sebagai institusi yang bergerak dalam pelayanan pendidikan. Tujuan kurikulum tiap satuan pendidikan harus mengacu kearah pencapaian tujuan pendidikan secara nasional, sebagaimana telah ditetapkan dalam Undang-Undang Tahun 2003 tentang Sistem Pendidikan Nasional. Pada skala yang lebih luas, kurikulum merupakan suatu alat pendidikan dengan tujuan untuk mengembangan sumberdaya manusia yang berkualitas.

\section{CONCLUSIONS}

Kurikulum merupakan kumpulan seperangkat rencana dan aturan yang diimplementasikan dalam lingkup pendidikan yang memuat nilai-nilai serta aspek-aspek yang disesuaikan dengan perkembangan zaman. Kurikulum berfungsi dalam membentuk dan mengembangkan aspek kognitif, afektif dan psikomotorik manusia dengan mencapai visi, misi, dan tujuan pendidikan nasional. Kurikulum sebagai alat dapat diwujudkan dalam bentuk program, yaitu kegiatan dan pengalaman belajar yang harus dilaksanakan oleh guru dan peserta didik dalam proses pembelajaran. Sifat kurikulum yang dinamis dan fleksibel serta selalu mengalami pergeseran dan perubahan mengikuti arah dan tujuan dari pendidikan yang mana setiap tahunnya kurikulum terus diperbaharui agar tidak tertinggal dari perkembangan zaman membuat kurikulum dapat dengan mudah diterapkan disetiap lembaga pendidikan. Tujuan dari kurikulum yaitu menghasilkan lulusan terbaik yang berilmu pengetahuan, berkarakter, menjunjung tinggi 
nilai-nilai norma budaya, moral, kebangsaan serta memiliki tingkat religiusitas yang tinggi.

\section{REFERENCES}

Abdullah, I. (2014). Pengembangan Kurikulum, Teori \& Praktik. Jakarta: Rajawali Pers.

Hidayati, A. (2014). Desain Kurikulum Pendidikan Karakter. Padang.

Bentri, A, Zelhendri Z \& Ulfia R. (2014). "Formulasi Strategi Penerapan Blended Learning dalam Implementasi Kurikulum di Jurusan KTP FIP Universitas Negeri Padang." Penelitian Pendidikan 5(1):22-30.

Bahri, S. (2011). "Pengembangan Kurikulum Dasar Dan Tujuannya." Jurnal Ilmiah Islam Futura XI(1):22-23.

Dakir. (2004). Perencanaan dan Pengembangan Kurikulum. Jakarta: Rineka Cipta.

Ismawati, E. (2012). Telaah Kurikulum Dan Pengembangan Bahan Ajar. Yogyakarta: Ombak.

Firman. dkk. 2013. "Penguatan Ilmu Pendidikan Untuk Menghasilkan Lulusan Terdidik

Dalam Implementasi Kurikulum 2013." Pp. 1-20 in Makalah Seminar Internasional. Medan: UNIMED PRESS.

Fitrah, M. 2015. “Peta Konsep Prinsip Relevansi Dalam Arah Pengembangan Kurikulum Matematika: Kajian Perspektif Pengembangan Kurikulum." Jurnal Sainsmat IV(1):42-50.

Babbit, F. (1918). The Curriculum. Boston: Hounghton Mifflin.

Ihsan, F. (2005). Dasar-Dasar Kependidikan. Jakarta: Rineka Cipta.

Hartatik, Yuliantai \&. Ninik Indawati. (2016). “Pengembangan Kurikulum PAUD (StudiKasus Di PAUD Citra KartiniDesa Senggreng - Kecamatan.Sumber Pucung Kabupaten Malang)." Jurnal Inspirasi Pendidikan 12(2):307.

Hasbullah. (2006). Dasar-Dasar Ilmu Pendidikan. Edisi Revi. Jakarta: Raja Grafindo Persada.

Hasbullah. (2007). Otonomi Pendidikan, Kebijakan Otonomi Daerah Dan Implikasinya Terhadap Penyelenggaraan Pendidikan. Jakarta: Raja Grafindo Persada.

Langeveld, M J, F. Bacher \&. H. Aebli. (1967). Paedagogica Europaea: The European Yearbook of Educational Research. Eropa: Council of Europe.

Mulyasa, E. (2012). Praktek Penelitian Tindakan Kelas. Bandung: PT Remaja Rosdakarya.

Mulyasa, E. (2009). Kurikulum Berbasis Kompetensi. Bandung: Remaja Rosda Karya.

Nursalam. (2016). Metodologi Penelitian Ilmu Keperawatan. Jakarta: Salemba Medika.

Hamalik, O. (2008). Kurikulum Dan Pembelajaran. Jakarta: Bumi Aksara.

Ririn, Rizal, \&. Sukardi. (2020). “Kontribusi Keterampilan Guru Abad 21 Terhadap Implementasi Kurikulum 2013 Di SMK 1 Sumbar Pendahuluan." JAIPTEKIN । Jurnal Aplikasi IPTEK Indonesia 4(2):69-74.

Doll, R. Caswe. (1974). Curriculum Improvement: Decision Making and Process. Boston: Allyn Bacon Inc.

Nasution, S. (1989). Kurikulum Dan Pengajaran. Jakarta: Rineka Cipta.

Sukmadinata \& Nana Syaodih. (2000). Pengembangan Kurikulum Teori Dan Praktek. Bandung: Remaja Rosda Karya.

Sukmadinata \& Nana Syaodih. (2015). Pengembangan Kurikulum. Bandung: Remaja Rosda Karya.

Suradnya, I. Made. (2009). “Pengembangan Kurikulum Pendidikan Dan Pelatihan Kepariwisataan Berkelanjutan." Jurnal Ilmu Pendidikan 16(3):162. 
Tamami, B. (2016). “Pengembangan Kurikulum PAI Di SMK Zainul Hasan Kecamatan Balung Kabupaten Jember Tahun Pelajaran 2013/2014." Jurnal Penelitian IPTEKS 3. Yamin, Martinis. (2012). Desain Baru Pembelajaran Konstruktivistik. Jakarta: Gaung Persada. Zainal Arifin. (2011). Konsep Dan Model Pengembangan Kurikulum. Bandung: Remaja Rosda Karya. 